Soil Science and Agricultural Engineering

http:/www.journals.zu.edu.eg/journalDisplay.aspx?Journalld=1\&queryType=Master

\title{
SITE-SPECIFIC RECLAMATION MAPS OF A SALT AFFECTED SOIL IN ISMAILIA GOVERNORATE
}

\author{
Reem A. Mohammed*, S.M. Shaddad, Atiat E. Nasrallah and Karam F. Moussa \\ Soil Sei. Dept., Fac. Agric., Zagazig Univ., Egypt
}

Received: 02/06/2019; Accepted: 02/07/2019

\begin{abstract}
Delineation of soil management zones is essential for precision agriculture applications, to know agricultural inputs added to soil. Geostatistics provides an effective tool for soil spatial variability and delineating management zones. Spatial variability was done on soil properties to prepare prescription maps for leaching and gypsum requirements (GR) of a salt affected soil. The performance of the spatial model was evaluated by calculating two different statistics. Mean error (ME) as a measure of precision and mean square standardized error (MSSE) as a measure of accuracy were calculated. The developed spatial maps of investigated soil parameters [electrical conductivity (ECe), exchangeable sodium percentage (ESP) and cation exchange capacity (CEC)] were used to specify 4 zones-prescription maps that need leaching and gypsum requirements. Results showed that the three models were precise and accurate with ME and MSSE values $(-0.110,-0.210,0.002$ and $0.937,1.033,1.010)$, respectively. Applying site-specific management for leaching proved costeffective and beneficial effects compared with traditional management which is based on an average value over the experimental field. The (GR) on basis of traditional management was cost-effective but was not more beneficial because zones 1 and 2 showed GR more than needed and vice versa for zones 3 and 4 . The high cost in this case could be counterbalanced by the expected increased production in zones with high ESP.
\end{abstract}

Key words: Kriging, salt affected soils, management zones.

\section{INTRODUCTION}

Salt affected soils are found in both arid and semi-arid regions affecting negatively plant growth and consequently low yield (Eilers $\boldsymbol{e t}$ al., 1997). In Egypt, salt-affected soils are located in the Northern-Central part of the Nile Delta and its Eastern and Western areas. They are also found in Wadi El-Natroun, El-Tal ElKebeir, the Oases, many parts of the Nile Delta and Valley and Fayoum Governorate. In Egyptian irrigated lands, about nine hundred thousand hectares suffer from salinization, distributed as follows: $60 \%$ is in Northern Delta, $20 \%$ in Southern Delta and Middle Egypt and $20 \%$ in Upper Egypt (FAO, 2007). Herrero and Pérez-Coveta (2005) and Benyamini et al. (2005) affermed the importance of spatial variability of salt affected soil which allow to

\footnotetext{
* Corresponding author: Tel. : +201017375484

E-mail address: Rerycasper@gmail.com
}

map and delineate management of zones of saline soils and how much agricultural inputs should be added to such soils. The problem of soil salinity can be solved by leaching soluble salts out of the root zone. Conventionally, data of soil properties are based on averages of soil analyses collected soil samples with no consideration of the spatial variations either at macro or micro scales within-field (NavarroPedreño et al., 2007; Webster and Oliver, 2007). Geostatistics is an effective tool to assess within field spatial variations of soil analyses used to delineate different management zones (Oliver and Webster, 2015). However geostatistical methods are time as well as money saving compared with the traditional methods since they provide a fine-scale information on soil variables. Spatial distribution of soil properties has been evaluated by several 
researchers (Burgess and Webster, 1980; Warrick et al., 1986; Odeh et al., 1992; Juang and Lee, 2000). The most common geostatistical prediction method was used to interpolate spatial distribution maps of the different soil properties is the ordinary kriging method (Meul and Van Meirvenne, 2003; Sumfleth and Duttmann, 2008; Lopez-Granados et al., 2015).

The current study aimed at evaluating the spatial distribution of soil salinity, sodicity, cation exchange capacity over a field in Ismailia Governorate using ordinary kriging for preparing site-specific management maps of leaching and gypsum requirements.

\section{MATERIALS AND METHODS}

\section{Site Description, Sampling and Laboratory Work}

This study was conducted on a 1.8-ha field $\left(30^{\circ} 25^{\prime} 47.42^{\prime} \mathrm{N}, 31^{\circ} 39^{\prime} 24.49 \mathrm{E}\right)$ located in ElKassasseen, Ismailia Governorate, Egypt (Fig. 1). One hundred soil samples from the $0-30 \mathrm{~cm}$ surface were taken based on a regular grid $20 \mathrm{~m}$ x $20 \mathrm{~m}$, for analyses. Analyses included electrical conductivity (EC) which was measured on soil paste extract according to Jackson (1973) and Slavich and Petterson (1993). Cation exchange capacity (CEC) was measured according to the barium chloride $(\mathrm{pH}$ 8.2) method, while soluble ions and SAR were measured according to Jackson (1973).

Exchangeable sodium percentage (ESP) was calculated using the following equation:

$$
\mathrm{ESP}=\frac{100(-0.0126+0.01475 \mathrm{SAR})}{1+(-0.0126+0.01475 \mathrm{SAR})}
$$

\section{Cited by USDA (1954).}

\section{Geostatistical Analysis}

The geostatistical analysis was implemented using ArcMap software 10.1 (USA), which consisted of the following steps:

1. Exploratory data analysis with the purpose of finding out whether the studied soil variables are normally distributed or not.

2. Calculation of the experimental semi-variogram for determining the spatial auto-correlation.
3. Fitting a model to the experimental semivariogram.

4. Interpolation using ordinary kriging.

\section{Prediction Assessment}

For evaluating the performance of prediction, cross validation was used (Isaaks and Srivastava, 1989) calculating two statistics to assess the precision and accuracy of estimation of the studied soil variables. The first statistic was the mean error (ME) as a bias indicator and the second was the mean standardized squared error (MSSE) (scaled by the predicted standard deviation of estimation), as an accuracy measure. The equations were as follows:

$$
\begin{gathered}
\text { ME }=\frac{1}{N} \sum_{i=1}^{N}\left(z_{i}-z^{*}\right) \\
\text { MSSE }=\frac{1}{N} \sum_{i=1}^{N}\left(\frac{z_{i}-z^{*}}{\sigma}\right)^{2}
\end{gathered}
$$

Where $\mathrm{N}$ is the number of active observations, $\sigma$ the kriging standard deviation, $Z^{*}$ is predicted value, $\mathrm{Zi}$ is measured value.

The first statistic should be close to zero implying that the estimation is unbiased whereas the second statistic should approximately equal 1 because it corresponds to the ratio between an experimental variance and a theoretical one (Carroll and Cressie, 1996).

\section{Calculations of Leaching Requirements for Delineated Zones}

Reclamation requirement was calculated using Reeve equation (1975), as follows:

$$
\frac{\mathrm{D}_{\mathrm{iw}}}{\mathrm{D}_{\mathrm{s}}}=\frac{\mathrm{EC}_{\mathrm{ei}}}{5 \mathrm{EC}_{\mathrm{ef}}}+0.15
$$

Where $D_{i w}$ is the depth of leaching water $(\mathrm{cm}), \mathrm{D}_{\mathrm{s}}$ is the depth of soil $(\mathrm{cm}), \mathrm{EC}_{\mathrm{ei}}$ and $\mathrm{EC}_{\mathrm{ef}}$ are soil salinity (in $\mathrm{dSm}^{-1}$ ) before and after leaching, respectively. Leaching requirement was calculated to reduce soil salinity to be $2 \mathrm{dS}$ $\mathrm{m}^{-1}$ for only zones having a mean value of ECe higher than $4 \mathrm{dS} . \mathrm{m}^{-1}$ for $0.20 \mathrm{~m}$ depth. The mean value and area of each delineated zones were calculated. 


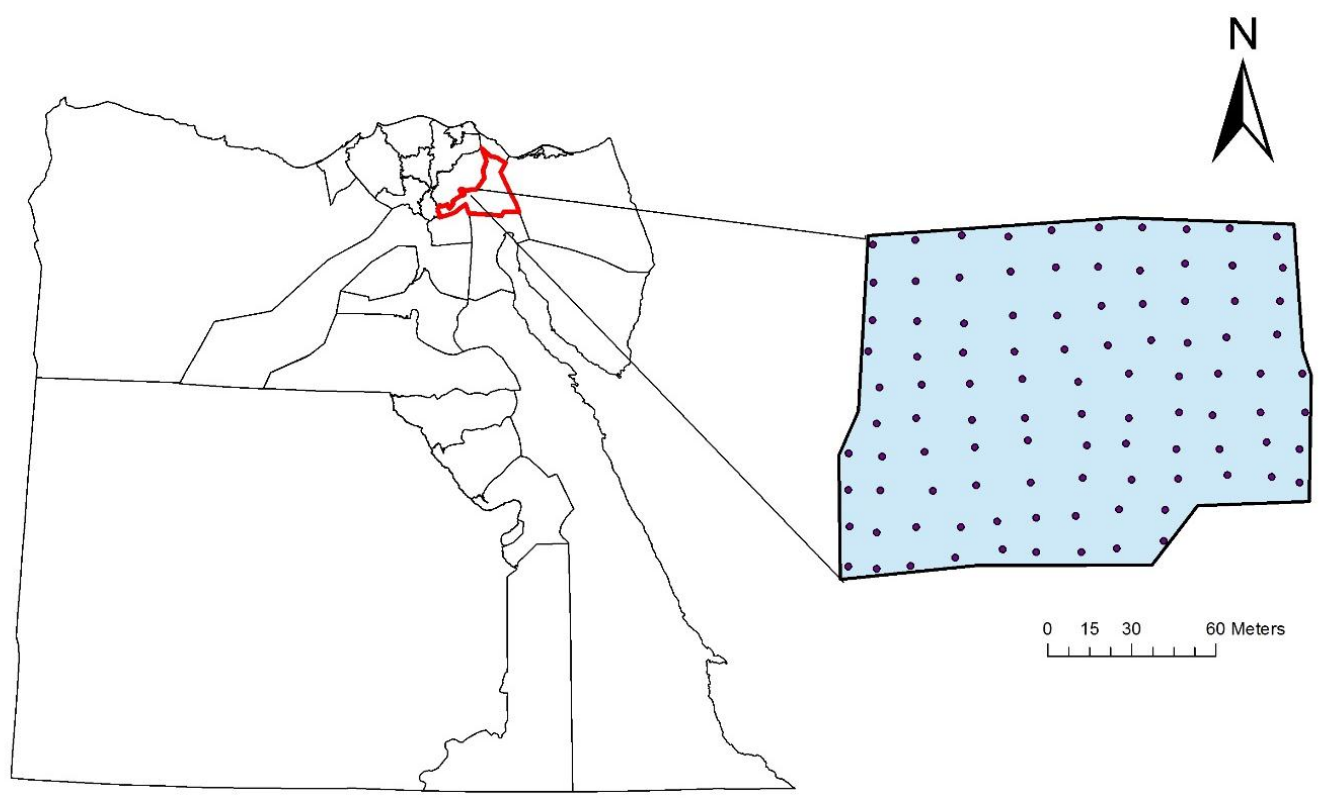

Fig. 1. Site location and soil sampling scheme

The leaching requirements was also calculated based on the average value of all samples (100) to quantify the water saved and make a reliable comparison between the two geostatistical and traditional methods.

\section{Calculation of the Gypsum Requirements (GR) of Each Delineated Zone}

GR was calculated based on the average value of ESP and CEC in each delineated zone using the following equation according to (USDA, 1954):

$$
\mathrm{GR}=\frac{\mathrm{ESP}_{\mathrm{i}}-\mathrm{ESP}_{\mathrm{f}}}{100} \times \mathrm{CEc} \times 4.09
$$

Where $\mathrm{ESP}_{\mathrm{i}}$ is the initial value and $\mathrm{ESP}_{\mathrm{f}}$ is the desired value to be reached. The GR is expressed as megagram per hectare $\left(\mathrm{Mg} \mathrm{ha}^{-1}\right)$ for a depth of $30 \mathrm{~cm}$ of soil surface.

\section{RESULTS AND DISCUSSION}

Results of the descriptive statistics are summarized in Table 1 where the studied soil variables are approximately symmetric since the skewness of ECe, ESP and CEC are 0.42, - 0.32 and 0.56 , respectively. Then, geostatistical analysis is applied directly without transformation.

Three different models were fitted to the experimental variograms of ECe, ESP and CEC.
These were stable, gaussian and spherical models for the soil variables, mentioned above, respectively (Table 2). The nugget to sill ratios indicates a moderate spatial dependence for ECe with a value of 0.312 and a strong spatial dependence for ESP and CEC with values of 0.226 and 0.057 , respectively.

Cross-validation results (Table 3) indicated that the three models were precise with ME values of $-0.011,-0.210$ and 0.002 for ECe, ESP and CEC, respectively. MSSE values were rather different from one but still within the tolerance interval $( \pm 3 \sqrt{2} / \mathrm{N}, \mathrm{N}$ is number of observations) (Chiles and Delfiner, 1999). However the three studied soil variables showed that the three models were accurate.

\section{Mapping}

\section{Soil salinity}

The spatial map of ECe shows four delineated zones with different ECe average values (Fig. 5). Zone 1 is characterized as non-saline soil and there is no need to apply leaching process since the ECe average value is less than $4 \mathrm{dSm}^{-1}$. The other three delineated zones had different mean values of ECe. These were 4.5, 5.93 and 7.64 $\mathrm{dSm}^{-1}$ for zones 2, 3 and 4, respectively. Most of zone 1 area was in the Western part of the field which might be due to the close of that area to the drain located in the Western part of the field. 
Table 1. Descriptive statistics of soil variables

\begin{tabular}{lccc}
\hline Statistic & ECe & ESP & CEC \\
\hline Mean & 5.84 & 32.71 & 24.34 \\
Standard Deviation & 2.07 & 9.92 & 4.59 \\
Kurtosis & -0.37 & 0.48 & -0.81 \\
Skewness & 0.42 & -0.32 & 0.56 \\
Minimum & 2.16 & 7.46 & 17.40 \\
Maximum & 11.11 & 52.84 & 33.00 \\
Count & 100 & 50 & 50 \\
\hline
\end{tabular}

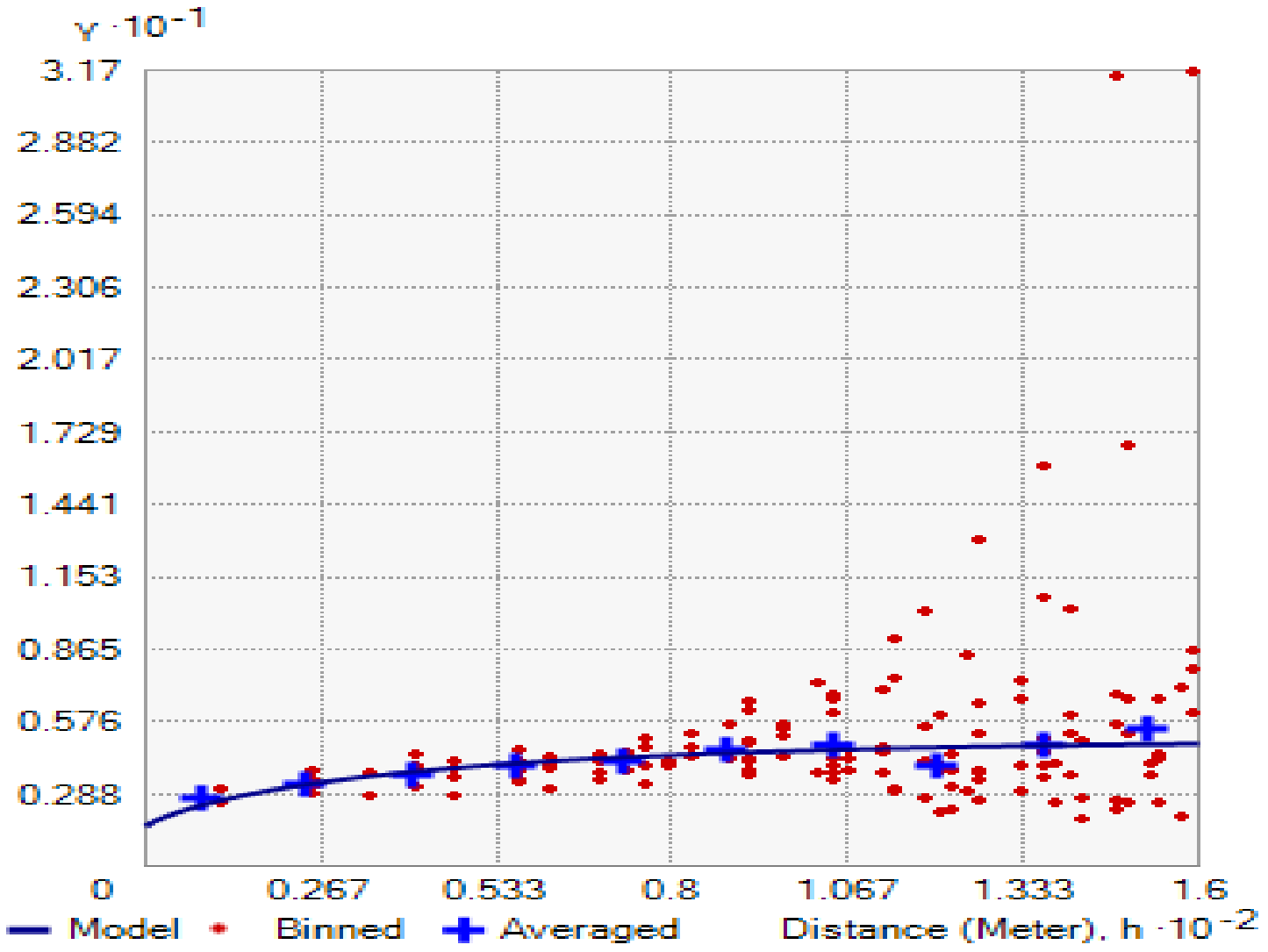

Fig. 2. Variogram model of ECe 


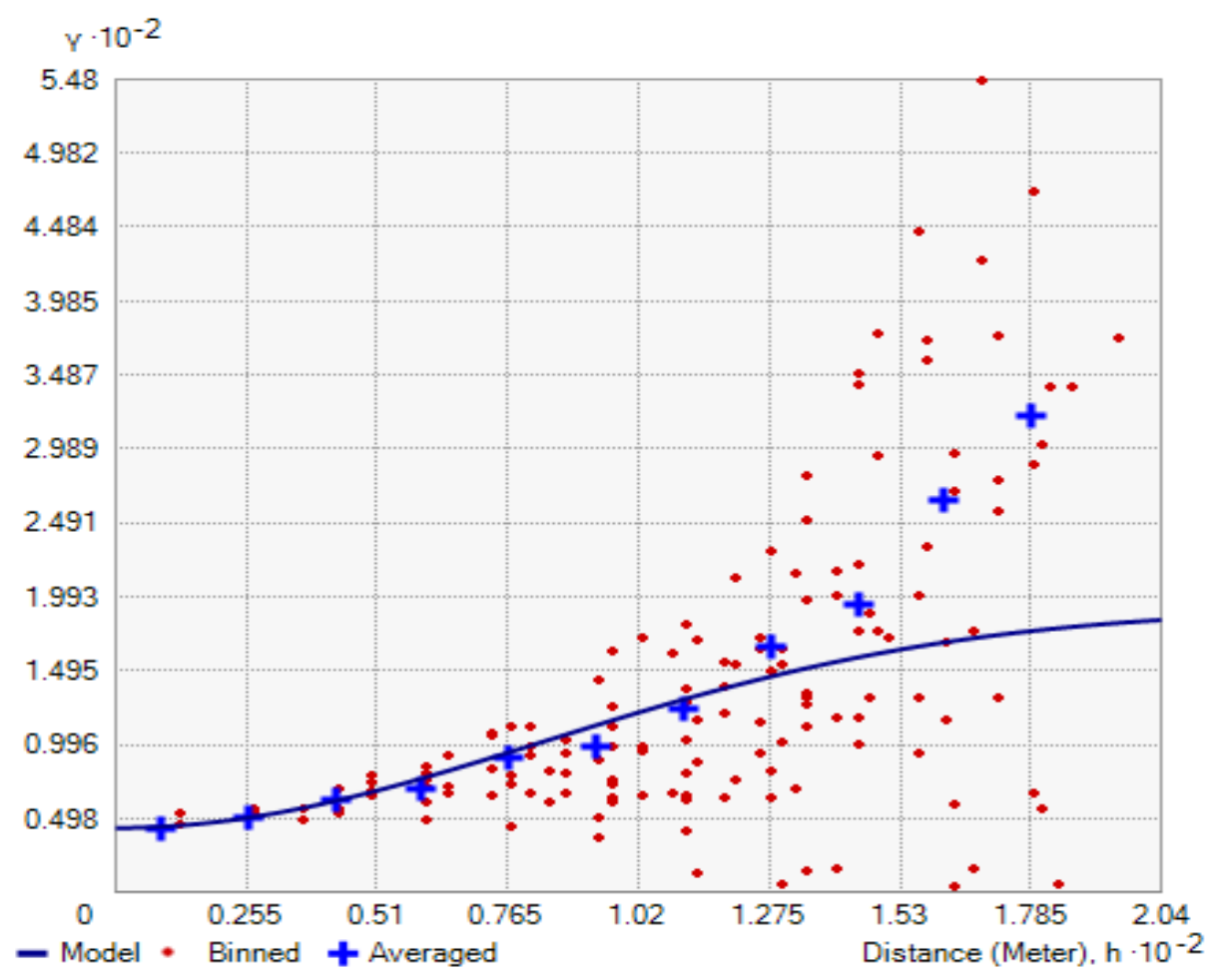

Fig. 3. Variogram model of ESP

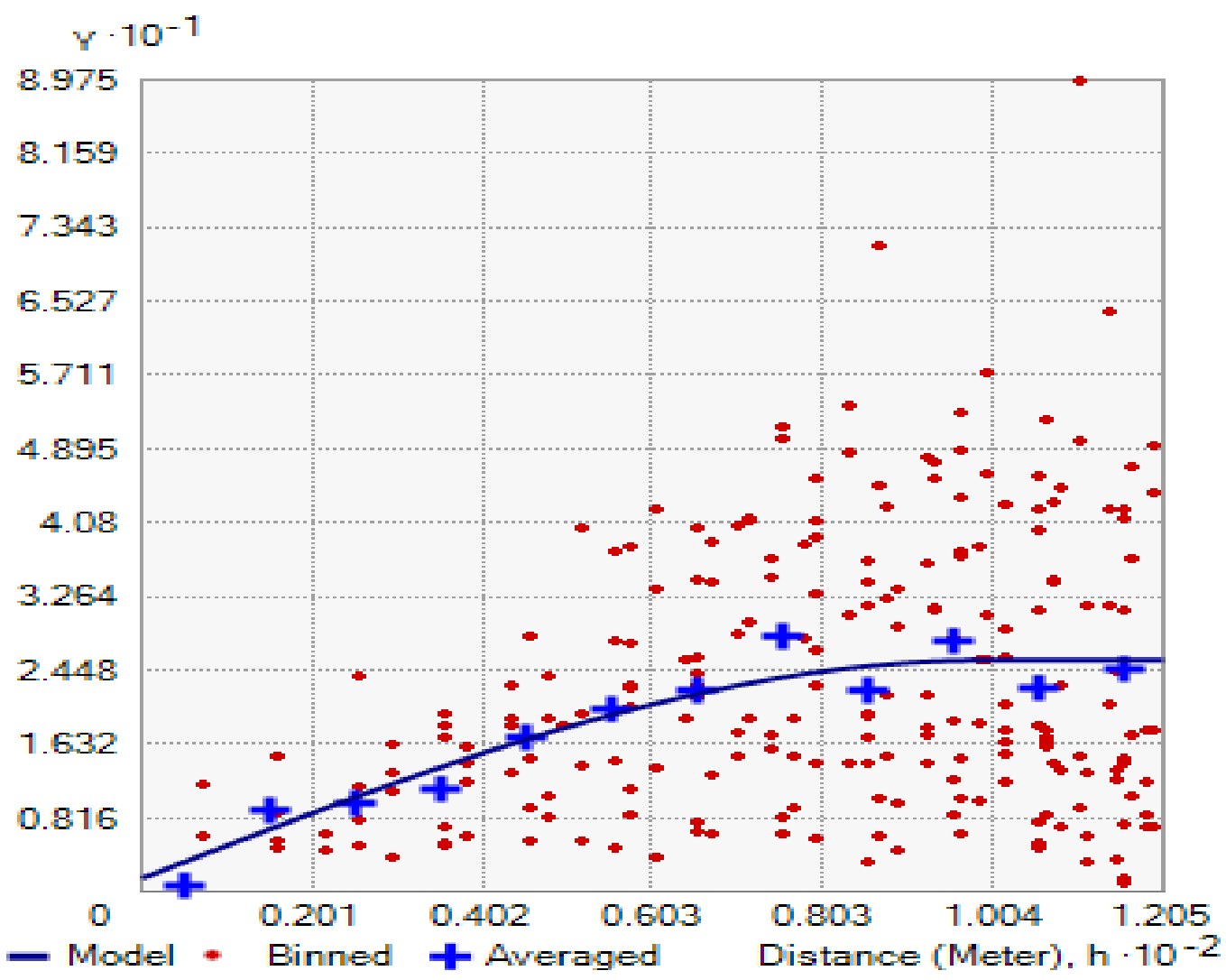

Fig. 4. Variogram model of CEC 
Table 2. Variogram model parameters of the studied soil variables

\begin{tabular}{lccccc}
\hline Variable & Model & Nugget effect & Partial sill & Range (m) & Nugget/sill \\
\hline EC $\left(\mathbf{d S ~ m}^{-1}\right)$ & Stable & 1.581 & 3.471 & 160 & 0.312 \\
ESP & Gaussian & 43.319 & 147.597 & 204 & 0.226 \\
CEC $\left(\mathbf{c m o l c ~ k g}^{-1}\right)$ & Spherical & 1.459 & 24.116 & 99.29 & 0.057 \\
\hline
\end{tabular}

Table 3. Cross-validation results

\begin{tabular}{lcccc}
\hline Variable & Count & ME & MSSE & Tolerance intervals \\
\hline EC $\left(\mathbf{d S ~ m}^{-1}\right)$ & 100 & -0.011 & 0.937 & $0.575-1.425$ \\
ESP & 100 & -0.210 & 1.033 & $0.575-1.425$ \\
CEC $\left(\mathbf{c m o l c ~ k g}^{-1}\right)$ & 50 & 0.002 & 1.010 & $0.400-1.600$ \\
\hline
\end{tabular}

Leaching requirements (Table 4) revealed that no leaching is needed for zone 1 whereas leachings (for $30 \mathrm{~cm}$ soil depth) for zones 2,3 and 4. Leaching water amounts were 646.47, 2009.88 and $1170.28 \mathrm{~m}^{3}$ for zones 2,3 and 4 , respectively. Such calculations are based on the ECe mean value for 100 soil samples $\left(5.84 \mathrm{dSm}^{-1}\right)$. Without geostatistical interpolation, a water amount of $4134.91 \mathrm{~m}^{3}$ of water should be added to reduce salinity of the total area to $2 \mathrm{dSm}^{-1}$. Thus, $308.28 \mathrm{~m}^{3}$ can be saved and then used for irrigation. These results emphasize the importance of geostatistical techniques in detecting within field variability and hence applying site-specific management.

\section{Soil sodicity}

Fig. 6 shows the spatial map of exchangeable sodium percent (ESP) over the area. Sodicity decreased towards the Southern West diagonal of the area. This may be attributed to the constructed drain network on the Western part of the field which is similar to the spatial distribution of ECe over the field.

A comparison between site-specific and traditional management for gypsum requirements (Table5) was calculated to find out which of them is cost effective or more efficient. Results showed that under site-specific management a total of 53.24 Mg of gypsum are needed to reach an ESP of 5 for the whole field, while under traditional management a total of $49.65 \mathrm{Mg}$ of gypsum are needed to reach an ESP of 5 for the whole field. This means that in this case, traditional management is apparently costeffective compared with site-specific management. However, the site-specific management is more efficient than the traditional management as the former allows to add the needed amount of gypsum where it is needed. Table 5 shows that zones 1 and 2 under traditional management would receive an amount of gypsum of 2.582 and $15.057 \mathrm{Mg}$, respectively each of which being more than needed. On the other hand, zones 3 and 4 would receive an amount of gypsum of 19.855 and $12.141 \mathrm{Mg}$, respectively which being less than needed under site-specific management. Such results indicate that applying site-specific management is more efficient even if traditional management is more economic. The high amount of gypsum under site-specific management could be counterbalanced by the increased production because of remediating soil sodicity especially in zones 3 and 4 which would receive gypsum less than needed.

\section{Conclusions}

Reclamation of salt affected soils is usually applied without taking spatial variation of soil salinity and sodicity into consideration. It may be cost-effective and more efficient to manage this on basis of management zones. This needs to recognize soil spatial variability and then delineate management zones. In this study, ordinary kriging was used to develop spatial maps of three soil properties of (ECe, ESP and 


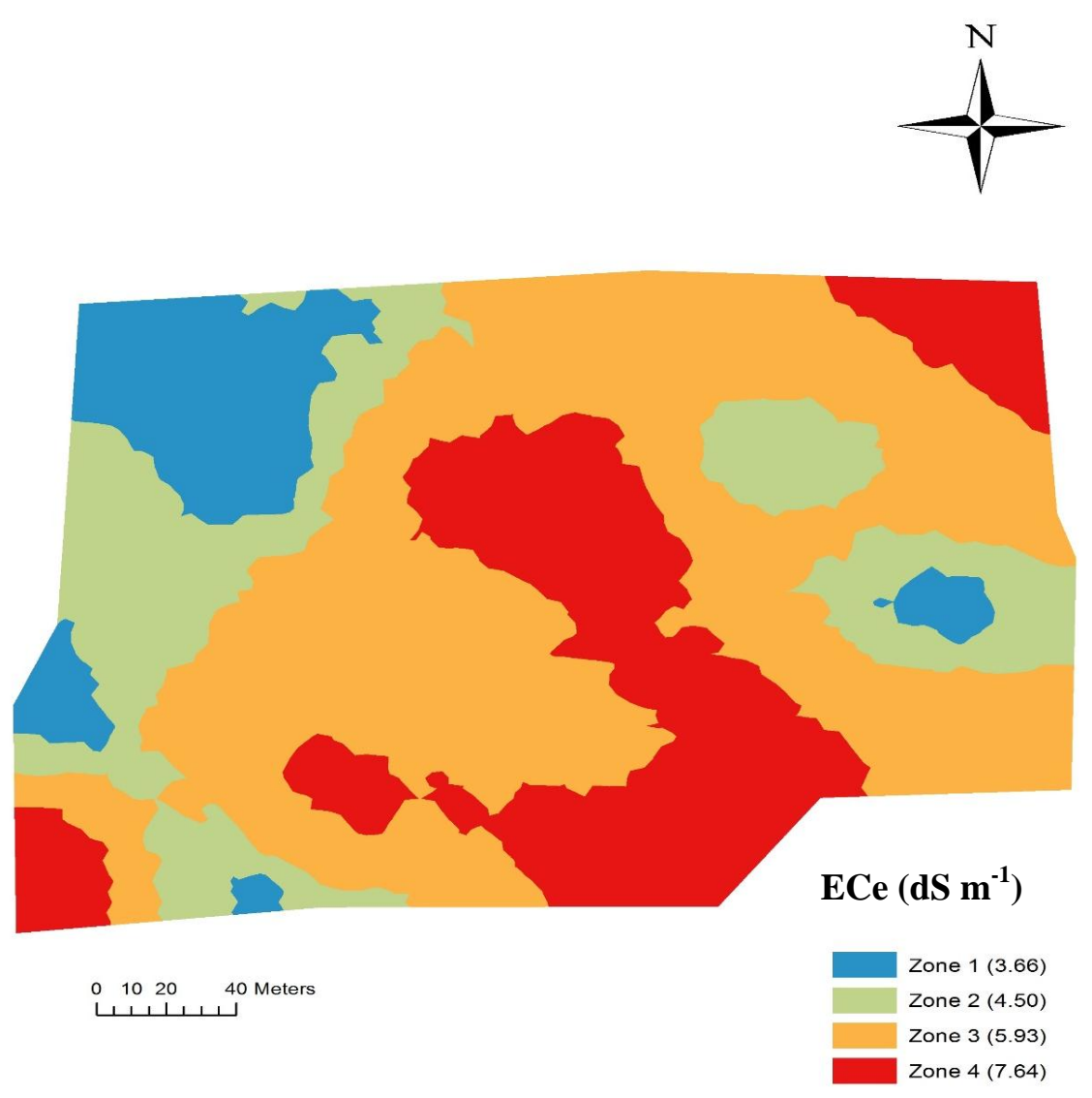

Fig. 5. ECe kriged map with mean value of each zone

Table 4. Leaching requirements for the delineated zones

\begin{tabular}{lccc}
\hline Zone & Area & ECe $\left(\mathbf{d S m}^{-\mathbf{1}}\right)$ & LR $\left(\mathbf{m}^{\mathbf{3}}\right)$ \\
\hline $\mathbf{1}$ & 1901 & 3.66 & ----- \\
$\mathbf{2}$ & 3593 & 4.50 & 646.47 \\
$\mathbf{3}$ & 9017 & 5.93 & 2009.88 \\
$\mathbf{4}$ & 4268 & 7.64 & 1170.28 \\
Average & & 5.84 & 4134.91 \\
Amount of water saved $\left(\mathbf{m}^{\mathbf{3}}\right)$ & & & 308.28 \\
\hline
\end{tabular}




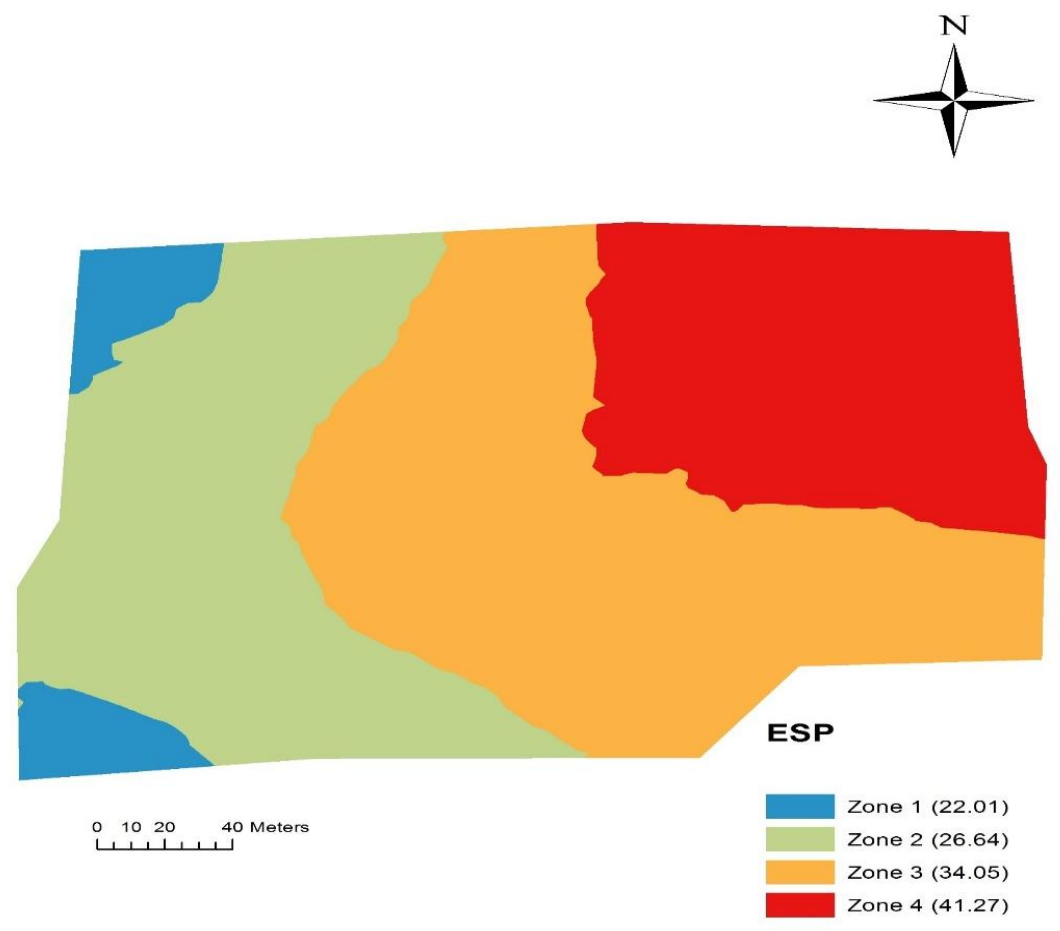

Fig. 6. ESP kriged map with mean value of each zone

Table 5. GR based on both site-specific and traditional management

\begin{tabular}{lccccc}
\hline Zone & $\begin{array}{c}\text { Area } \\
\left(\mathbf{m}^{\mathbf{2}}\right)\end{array}$ & $\begin{array}{c}\text { ESP } \\
(\boldsymbol{\%})\end{array}$ & $\begin{array}{c}\text { CEC } \\
\left(\mathbf{c m o l}_{\mathbf{~}} \mathbf{~ k g}^{-\mathbf{1}}\right)\end{array}$ & $\begin{array}{c}\text { GR Mg/zone based } \\
\text { on site-specific } \\
\text { management }\end{array}$ & $\begin{array}{c}\text { GR Mg/zone based } \\
\text { on traditional } \\
\text { application }\end{array}$ \\
\hline $\mathbf{1}$ & 977 & 22.01 & 24.00 & 1.63 & 2.582 \\
$\mathbf{2}$ & 5696 & 26.64 & 23.12 & 11.67 & 15.057 \\
$\mathbf{3}$ & 7511 & 34.05 & 23.14 & 20.68 & 19.855 \\
$\mathbf{4}$ & 4593 & 41.27 & 28.23 & 19.26 & 12.141 \\
Total samples average & 18778 & 32.71 & 24.34 & 53.24 & 49.65 \\
\hline
\end{tabular}

CEC). A comparison between site-specific management and traditional management was carried out to verify which approach is more beneficial. Results showed that under sitespecific management a quantity of water was saved and can be used for irrigation. For gypsum requirement, traditional management was apparently cost effective. However this could be counterbalanced by increased production in zones with high level of sodicity.

\section{REFERENCES}

Benyamini, Y., V. Mirlas, S. Marish, M. Gottesman, E. Fizik and M. Agassi (2005). A survey of soil salinity and groundwater level control systems in irrigated fields in the Jezre'el Valley, Israel. Agric. Water Manag., 76: 181-194.

Burgess, T.M. and R. Webster (1980). Optimal interpolation and isarithmic mapping of soil 
properties: I. The variogram and punctual kriging. J. Soil Sci., 31: 315-331.

Carroll, S.S. and N. Cressie (1996). A comparison of geostatistical methodologies used to estimate snow water equivalent. J. Ame. Water Res. Assoc., 32 (2): 267-278.

Chilès, P. and P. Delfiner (1999) Geostatistics: Modelling Spatial Uncertainty. Wiley, New York, 695.

Eilers, R.G., W.D. Eilers and M.M. Fitzgerald (1997). A salinity risk index for soils of the Canadian Prairies. Hydrogeol. J., 5: 68-79.

FAO (2007). Land and plant nutrition management service. [Online]. Available: http://www. fao. org/ag/AGL/agll/prosoil/saline.htm. Problem Soils database.

Herrero, J. and O. Pérez-Coveta (2005). Soil salinity changes over 24 years in a Mediterranean irrigated district. Geoderma, 125: 287-308.

Isaaks, E.H. and R.M. Srivastava (1989) An Introduction to Applied Geostatistics. Oxford Univ. Press, 561.

Jackson, M.L (1973). Soil Chemical Analysis. Prentice Hall, Ic., Englewood Califfs, New Jersy.

Juang, K.W. and D.Y. Lee (2000). Comparsion of three nonparametric kriging methods for delineating heavy-metal contaminated soils. J. Environ. Qual., 29: 197-205.

Lopez-Granados, F., M. Jurado-Exposito, J.M. Pena-Barragan and L. Garcia-Torres (2015). Using geostatistical and remote sensing approaches for mapping soil properties. Eur. J. Agron., 23: 279 - 289.

Meul, M. and M. Van Meirvenne (2003). Kriging soil texture under different types of nonsationarity. Geoderma, 112: $217-233$.
Navarro-Pedreño, J., M.M. Jordan, I. MeléndezPastor, I. Gómezi, P. Juan and J. Mateu (2007). Estimation of soil salinity in semiarid land using a geostatistical model. Land Degrad. Develop., 18 : 339-353.

Odeh, I.O.A., A.B. McBratney and D.J. Chittleborough (1992) Fuzzy-c means and kriging for mapping soil as continues system. Soil Sci. Soc. Ame. J., 56: 1848-1854.

Oliver, M.A. and R. Webster (2015). Basic Steps in Geostatistics: The Variogram and Kriging, Springer Briefs in Agric., DOI 10.1007/978-3-319-15865-5_1.

Reeve, R.C. (1975). The relation of salinity to irrigation and drainage requirement. $3^{\text {rd }} \mathrm{Ed}$. Cong. on Irrigation and Drainage. Tran., 5: 157-187.

Slavich, P.G. and G.H. Petterson (1993). Estimating the critical conductivity of saturated paste extracts from 1:5 soil: water suspensions and texture. Aust. J. Soil Res., 73-81.

Sumfleth, K. and R. Duttmann (2008). Prediction of soil property distribution in paddy soil landscapes using terrain data and satellite information as indicators. Ecol. Indic., 8 : $485-501$.

USDA (1954). Diagnosis and Improvement of Saline and Alkali Soils. United State Department of Agriculture (USDA). Handbook 60 Washington DC, USA.

Warrick, A.W., D.E. Myer and D.R. Nielsen (1986). Geostatistics methods applied to soil science. In A. Klute (ed.) methods of soil analyses part 1: Physical and mineralogical methods. ASA and SSSA, Madison, WI, USA, 53-82.

Webster, R. and M.A. Oliver (2007). Geostatistics for Environmental Scientists. $2^{\text {nd }}$ Ed. John Wiley and Sons, Ltd, London, UK. 


\section{خــرائط اســـتصلاح نطاقية لأرض متأثــــرة بالأمسـلاح فـي محـافظـــة الإســـاعيليــة}

$$
\begin{aligned}
& \text { ريم عبدالرؤف محمد ـ سامع محمد شداد ـ عطيات السيد نصر الله ـ كرم فؤاد موسى }
\end{aligned}
$$

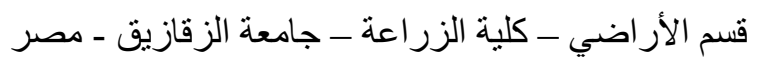

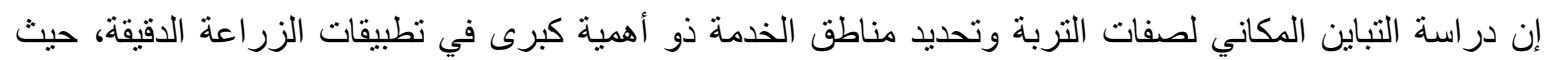

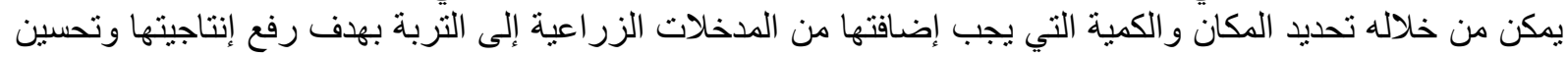

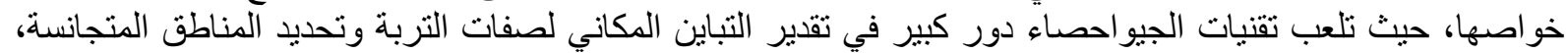

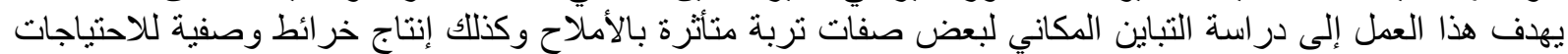

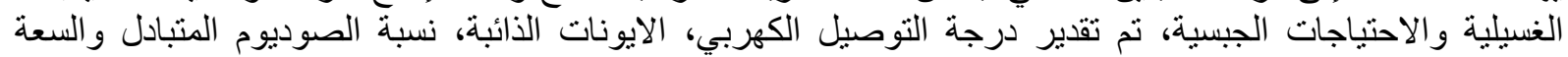

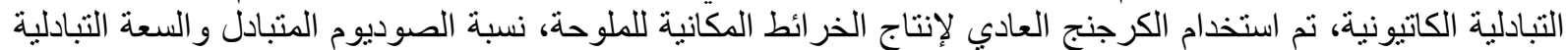

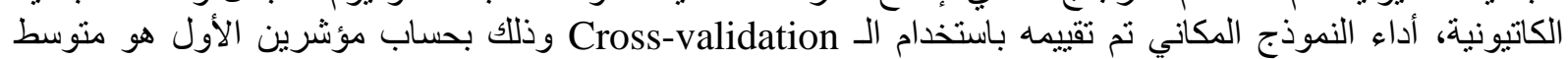

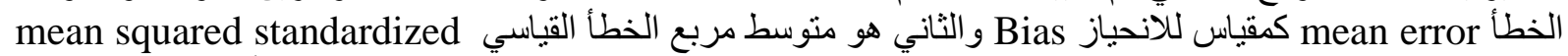

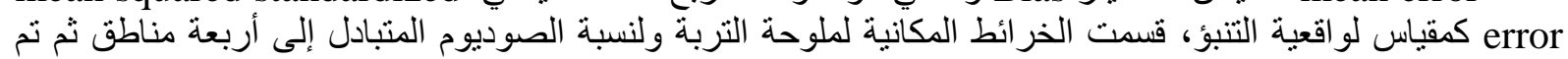

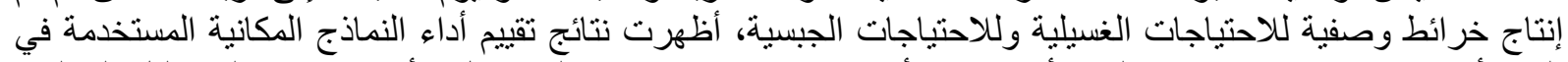

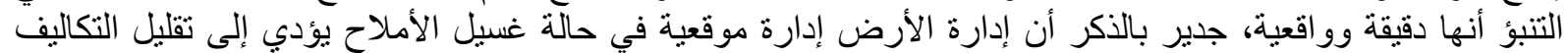

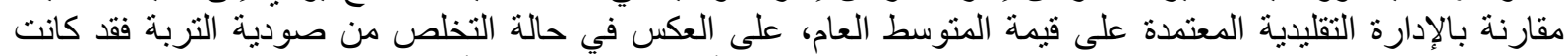

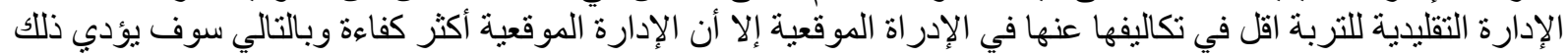
إلى زيادة الإنتاج و الذي بدوره قد يغطي الفرق في التكاليف بل قد ينتج عنه ربح الإدالئ

أستاذ الأر اضي المتفرغ - كلية الزر اعة بمشتهر - جامعة بنها. أستاذ الأراضي المساعد - كلية الزر اعة - - جامعة الزفازيق.
المحكمــــــون: 